\title{
Reproductive phase determination in male meagre (Argyrosomus regius, Sciaenidae): testis development and histologic corroboration of a gross anatomical scale
}

\author{
Nuno Prista ${ }^{1,2,4}$, Leonel Gordo ${ }^{1,2}$, José Lino Costa ${ }^{1}$, Maria José Costa ${ }^{1,2}$, Cynthia Jones ${ }^{3}$ \\ ${ }^{1}$ Centro de Oceanografia, Faculdade de Ciências da Universidade de Lisboa, Campo Grande, 1749-016 Lisboa, Portugal. \\ E-mail: nmprista@ipma.pt \\ ${ }^{2}$ Departamento de Biologia Animal, Faculdade de Ciências da Universidade de Lisboa, Campo Grande, \\ 1749-016 Lisboa, Portugal. \\ ${ }^{3}$ Center for Quantitative Fisheries Ecology, Old Dominium University, 800W 46 ${ }^{\text {th }}$ St., Norfolk, VA 23508, USA \\ ${ }^{4}$ Present address: Instituto Português do Mar e da Atmosfera, Avenida de Brasília, 1449-006 Lisboa, Portugal.
}

\begin{abstract}
Summary: Reproductive stage determination of male gonads has received sparse attention in fish biology literature with few studies detailing the building of gross anatomical- and histologic scales. The meagre (Argyrosomus regius) is one of the world's largest sciaenids and supports a significant regional fishery in European and North African waters whose reproductive patterns are yet to be fully investigated. In the present study, we derive a macroscopic grading system for meagre testis using semi-quantitative graphs that feature the testis variability along the species size range and time of the year. We then describe the histological stages and reproductive phases of male testes and determine the extent to which they corroborate the anatomical scale. Our results indicate that gross anatomical analyses are accurate in assessments of the meagre spawning season but may not precisely distinguish the testes of well-mature fish and first spawning virgins. Furthermore, we show that milt expression varies widely with size and misclassifies as immature many smaller fish in spawning-capable condition. We discuss these findings in terms of their contribution to the understanding of testes development and the uncertainties involved in determining the size-at-maturity of male fish using gross anatomical scales.
\end{abstract}

Keywords: histology; testes; reproduction; males; validation; Argyrosomus regius.

Determinación de la fase reproductiva en los machos de la corvina (Argyrosomus regius, Sciaenidae): desarrollo de los testículos y corroboración de una escala anatómica

Resumen: La determinación de la etapa reproductiva de las gónadas masculinas ha recibido escasa atención en la literatura con poca información disponible sobre la construcción de escalas macroscópicas e histológicas. La corvina (Argyrosomus regius) es uno de los más grandes esciaénidos mundiales y registra pesquerías regionales significativas en las aguas europeas y del norte de África pero sus patrones reproductivos han sido poco investigados. En el presente estudio, se deriva un sistema de clasificación macroscópica para los testículos de la corvina utilizando gráficos semi-cuantitativos que contemplan la variabilidad de los testículos respecto al tamaño de los ejemplares a lo largo del año. A continuación se describen las etapas histológicas y fases reproductivas de los machos y se corrobora la escala macroscópica. Nuestros resultados indican que los análisis macroscópicos son exactos en las evaluaciones de la estación de puesta pero pueden no ser capaces de distinguir con precisión los testículos de peces bien maduros y en la primera madurez. Además, se muestra que la expresión de esperma varía con el tamaño del pez lo que puede dar lugar a clasificar erróneamente como inmaduros peces jóvenes que se encuentran en condiciones de puesta. Estos resultados se discuten en términos de su contribución a la comprensión actual del desarrollo de los testículos y de las incertidumbres que rodean el uso habitual de las escalas macroscópicas en la valoración de la talla de madurez de los peces machos.

Palabras clave: histología; testículos; reproducción; machos; validación; Argyrosomus regius.

Citation/Como citar este artículo: Prista N., Gordo L., Costa J.L., Costa M.J., Jones C. 2014. Reproductive phase determination in male meagre (Argyrosomus regius, Sciaenidae): testis development and histologic corroboration of a gross anatomical scale. Sci. Mar. 78(1): 65-80. doi: http://dx.doi.org/10.3989/scimar.03837.31A

Editor: E. Massuti.

Received: March 4, 2013. Accepted: October 31, 2013. Published: February 24, 2014.

Copyright: (c) 2014 CSIC. This is an open-access article distributed under the Creative Commons Attribution-Non Commercial Lisence (by-nc) Spain 3.0. 


\section{INTRODUCTION}

The meagre (Argyrosomus regius, Asso 1801) is one of the world's largest sciaenids, attaining over $180 \mathrm{~cm}$ in total length and $50 \mathrm{~kg}$ in weight (Quéméner 2002). Its distribution ranges from the English Channel to Senegal (including the Mediterranean Sea and the Black Sea). Most of the year the meagre occurs in coastal waters $(<80 \mathrm{~m}$ deep) but in spring and summer it migrates to shallow coastal waters and/or large European estuaries that it uses as spawning and nursery grounds (Quéro and Vayne 1987). The largest meagre fisheries take place in Mauritania, Morocco, and Egypt, which together comprise over $80 \%$ of the ca. $10000 \mathrm{t}$ world annual catch (Quéméner 2002, FAO 2009). In Europe, national meagre landings are generally below 500 t/year (FAO 2009) but due to its large size, high ex-vessel prices and seasonal availability in inshore and nearshore waters, it is an important target species for local small-scale commercial and recreational fleets (Quéro and Vayne 1987, Quéméner 2002, Prista et al. 2008). This importance is underscored by the recent development of meagre aquaculture production and by the ecological significance of the meagre as a top marine predator in European coastal waters (Quéro and Vayne 1987, Quéméner et al. 2002, Schiavone et al. 2012). However, to date the biological characteristics of the meagre have remained scarcely studied worldwide and its fisheries have yet to be routinely monitored or assessed in both African and European waters (Prista et al. 2011).

Studies of gonad morphology at both anatomical and histological levels have long been done by fish biologists to identify reproductive cycles, spawning seasons and breeding areas, or to determine size-atmaturity (Hunter and Macewicz 2003). In fisheries science, the determination of the reproductive state of a fish population in a specific area, time, and/or size class plays a vital role because these parameters are closely related to stock productivity and are the basis of many regulatory measures (e.g. minimum landing size) (Hunter and Macewicz 2003). Until recently, the reproduction of meagre had only been studied in North African waters on the basis of macroscopic observations of fish gonads and the monthly evolution of gonadosomatic indexes (Tixerant 1974, Hermas 1995). From 2000 onwards increased interest in aquaculture production and concern with data-poor regional fisheries sparked research and led to a new array of studies (e.g. González-Quirós et al. 2011, Prista et al. 2011, Abou Shabana et al. 2012, Morales-Nin et al. 2012, Schiavone et al. 2012, Gil et al. 2013). Among these are descriptions of the meagre life cycle in the Gulf of Cádiz (González-Quirós et al. 2011, Morales-Nin et al. 2012), two studies of meagre reproduction in aquaculture facilities (Schiavone et al. 2012, Gil et al. 2013), and one study that analyses the reproduction of males of wild meagre but with a very limited sample size (Abou Shabana et al. 2012).

Macroscopic maturity scales (also known as the gross anatomical grading systems) of fish ovaries and testes are among the most frequently used indexes in assessments of fish reproductive condition (West 1990, Hunter and Macewicz 2003). The use of these methods is rooted in historical fish biology literature and their inexpensiveness and fast applicability-along with proven capabilities to detect major reproductive events (namely spawning season) - have built them into routine research protocols of nearly every fisheries survey in the world. However, several authors have warned of their imprecision and biases in assessments of reproductive parameters that require fine resolution (e.g. size-at-maturity). Such flaws can be circumvented through validation studies in which independent histological observations (assumed to accurately reflect the internal development of fish gonads) are used to fine tune the anatomical scales and estimate their biases (West 1990, Hunter and Macewicz 2003, BrownPeterson et al. 2011).

Historically, the vast majority of histological studies concerning fish reproduction have addressed female reproduction, with less information being available on male reproduction (Grier et al. 1987, Parenti and Grier 2004, Lowerre-Barbieri et al. 2011, Brown-Peterson et al. 2011). However, the recent fish reproduction literature in ecology, fisheries and aquaculture has increasingly noted the importance of fully understanding male reproductive patterns (Parenti and Grier 2004, Brown-Peterson et al. 2011) because males may have different reproductive parameters from females such as a different span of spawning seasons and a different size-at-maturity (Grau et al. 2009, Lowerre-Barbieri et al. 2011). Pin-pointing and understanding such differences is biologically significant and important for fisheries because they constitute the supporting evidence underlying frequently adopted management measures (e.g. minimum landing size).

In this study we provide the first detailed description of meagre testis development at macroscopic (anatomical) and microscopic (histologic) level. In doing this, we describe the size-related and seasonal variability of macroscopic and microscopic characteristics and use these to build an anatomical scale and a histological scale. Then, we the compare histological and macroscopic information and use these results to corroborate the anatomical scale, identify its main biases and discuss how they can be minimized. To our knowledge, these results constitute the first comprehensive reproductive study of testes from wild meagre in European waters and also one of the first attempts at the step-by-step construction and histological corroboration of an anatomical grading system for fish testes.

\section{MATERIALS AND METHODS}

\section{Sampling methodology}

A total of 2418 meagres were sampled from 2003 to 2007 during a large-scale study that targeted the meagre fishery and biology on the Portuguese coast. Detailed coverage of the sampling methodologies, the fisheries and areas covered can be found in Prista et al. (2007, 2008) and Costa et al. (2008). Biological sampling was carried out monthly in two geographical areas that 
Table 1. - Main characteristics used in the macroscopic analysis of meagre testes.

\begin{tabular}{|c|c|}
\hline Characteristic & Classification levels \\
\hline Coloration & White; Yellow; Orange; Red; Brown \\
\hline $\begin{array}{l}\text { Overall shape of gonad lobe (in } \\
\text { ventral view) }\end{array}$ & Rectangular; Triangular; Lozenge; Too thin to characterize; Other \\
\hline Shape of gonad cross-section & $\begin{array}{l}\text { Rectangular; Triangular I (acute triangle; generally equilateral); Triangular IIa (rectangular; } \\
\text { generally isosceles); Triangular IIb (rectangular; generally isosceles; with proximal sulcus on } \\
\text { proximal side of testicle); Too thin to characterize }\end{array}$ \\
\hline Fullness & Turgid (full); Not turgid (“half” full); Flaccid (empty-looking) \\
\hline Thickness of gonad wall & Thin; Thick \\
\hline Presence of ventral striae & Present; Absent; Gonad too thin to characterize \\
\hline Reaction to abdominal pressure & Positive (leaks semen upon thumb-rubbing); Negative (no leakage of semen upon thumb-rubbing) \\
\hline Reaction to pressure & Ruptures immediately; Offers resistance; Does not rupture ("rubberish") \\
\hline Presence of blood "dots" & Present and conspicuous; Absent or inconspicuous \\
\hline
\end{tabular}

encompass the main meagre fisheries in Portugal: the Tagus estuary (central-western coast) and the coast of Olhão (southern coast). Monthly sampling goals were set at 10 males per $10-\mathrm{cm}$ size class following the requirements of a concurrent age and growth study with effectively achieved goals largely dependent on the seasonal availability of the fish in the two geographical areas. In general, all meagre specimens were measured (total length) and weighed (total weight), and had their abdomen slightly squeezed for expressible milt or roe. Whenever possible, the individuals were gutted and sexed, and their gonads were weighed (to the nearest $1 \mathrm{~g}$ ), checked for the presence of the large-bodied female nematodes of the genus Philometra (Moravec et al. 2007) and analysed for macroscopic characteristics and/or preserved for histology. In general, otoliths were removed and later processed for age determination following Prista et al. (2009).

\section{Macroscopic analysis}

Meagre testes were subjected to macroscopic classification with respect to a set of pre-defined characteristics (Table 1). The set included characteristics reported in previous meagre studies (Tixerant 1974) and in studies of other large sciaenids (Murphy and Taylor 1990, Griffiths 1996, Farmer 2003), and two characteristics that were found varying with fish size and/or season: a) the presence/absence of a groove running longitudinally along the proximal side of each testicle which makes this side appear concave (hereafter termed the proximal groove) and b) the presence/absence of striae, generally over two centimetres long, running longitudinally on the ventral surface of spent testicles (hereafter termed ventral striae). Objectively defined levels were set for each morphological feature with no a priori judgment of gonad maturity being made. To make the observation of each morphological feature more objective and reduce observation biases, the laboratory protocol involved the observation of the several features, one at a time, across the several fish from each sample, and only in the end were the gonads photographed and coarsely graded as to their overall macroscopic appearance. A final anatomical grading system was later obtained from analysis of variations in the frequency of occurrence of each macroscopic character- istic across size (within the peak spawning season) and months (in mature fish). In these analyses, the peak spawning season was considered to be May and June (Costa et al. 2008) and fish were assumed to be mature fish at $80 \mathrm{~cm}$ (Tixerant 1974).

\section{Histological analysis}

Male gonads were fixed and preserved in $4 \%$ buffered formaldehyde (buffer: $\mathrm{Na}_{2} \mathrm{HPO}_{4}$ and $\mathrm{NaH}_{2} \mathrm{PO}_{4} * \mathrm{H}_{2} \mathrm{O}$ ) and stored in plastic boxes. Good preservation of large testes was assured by carefully injecting a small amount of fixative through the gonad wall with a syringe. When testis volume was too large, only the left lobe was preserved. Histological procedures were carried out on small pieces of meagre gonad (about $0.125 \mathrm{~cm}^{3}$ ) taken from the ventral periphery of the medial region of the lobe. In general, the pieces included a full cross-section of the testes (from the periphery to the lumen); in larger testes, however, only the periphery and middle regions were represented. Histological preparation of gonads involved successive alcoholic dehydratations, infiltration, sectioning, mounting and staining. Technovit 7100 resin (Heraeus Kulzer) was used as the embedding medium and a Leica RM2155 micrometer was used to obtain thin sections (3-5 $\mu \mathrm{m}$ thick). The sections were stained with toluidine blue, a basophilic metacromatic stain. Three replicate sections were mounted on each slide. Permanent preparations were obtained using Neomount and Neoclear (Merck). Microscopic analyses were carried out at 40-400× magnification on a Zeiss stereomicroscope equipped with the Axioplan 2 imaging system. Digital pictures of histological slides were taken at 200-400× magnification with an AxioCam and processed and measured using AxioVision 4 (Zeiss). Image processing after capture was restricted to resizing, contrast and brightness adjustments, and minor background clean-ups.

The description of male gametogenesis follows Parenti and Grier (2004) and Dadzie and Abou-Seedo (2004), along with the recently proposed unifying terminology of Brown-Peterson et al. (2011). Slides were examined after randomizing slide boxes in order to minimize bias in structure identification. The final histological grading system developed for male meagre was based on a) overall testis structure, b) the 
relative abundance of the several germinal epithelium (GE) developmental stages, c) the continuity or discontinuity of the GE, d) abundance of spermatozoa in the lobule lumen, and f) the thickness of the testis wall (Dadzie and Abou-Seedo 2004, Brown-Peterson et al. 2011). Overall testis appearance was graded as "compact", "compact(at periphery)->tubular(closer to core)" and "tubular". The development stages of the GE included primary and secondary spermatogonia, primary and secondary spermatocytes, spermatids, and spermatozoa. The relative abundance of each GE stage was graded as " ++ " (very abundant), "+" (abundant), "_" (scarce) and " 0 " (absent), based on a consensus between the replicates on each slide. The continuity of the GE was graded as "compact", "continuous", "discontinuous" and "regenerating" (spermatogonia regeneration). Wall thickness was classified as "thin" and "thick". Cell diameters reported on descriptions of spermatogenesis stages were obtained from measurements of five cells per individual in each of five individuals randomly sampled from within the ones known to carry cysts of each developmental stage. Final testis development phases follow the recent standardization proposed by Brown-Peterson et al. (2011), whose conceptual model considers "immatures" (fish that never spawned), "developing" (fish whose testes are beginning to grow and developing), "spawning-capable" (fish that are developmentally and physiologically able to spawn in the current year), "regressing" (sexually mature fish that have finished spawning) and "regenerating" (sexually mature fish that are reproductively inactive). A full account of the histological details of each development phase can be found in Brown-Peterson et al. (2011).

\section{Histological corroboration of the anatomical scale}

To evaluate the extent to which the gross anatomical scale reflects the histological structure of testes in male meagre specimens and corroborate the use of the anatomical scale in routine sampling of meagre in the field, the results of the anatomical scale were compared with the ones obtained from histological analysis using the subset of testes in which both scales had been applied. These comparisons considered the histological

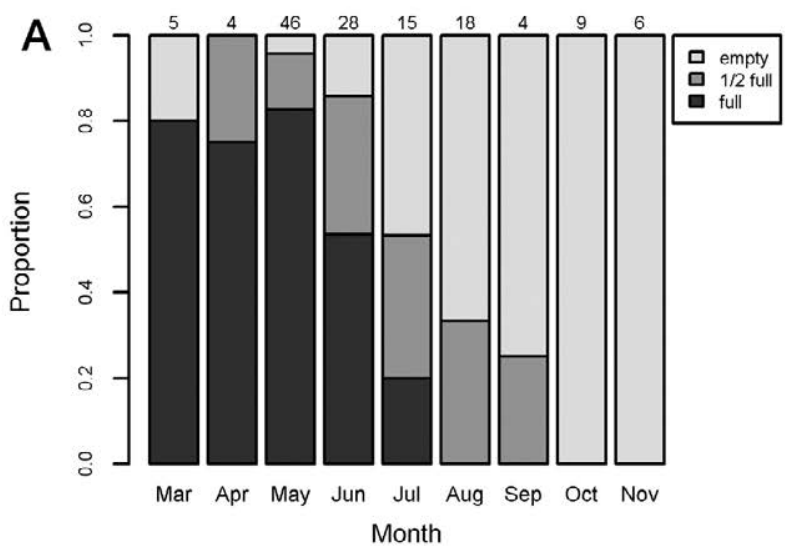

classification to represent the "truth" because histology is widely regarded as the most accurate staging method for fish gonads (Hunter and Maciewicz 2003, Costa 2009, Ferreri et al. 2009).

\section{RESULTS}

\section{Anatomical classification scale}

A total of 242 testes were subjected to macroscopic analyses. These included 234 testes taken from the monthly-length stratified sampling of sexed individuals and gonads from eight immature fish whose sex could not be macroscopically determined. Testes subjected to macroscopic analyses came from fish captured in estuarine $(n=123)$ and coastal $(n=114)$ fishing grounds from both the western $(n=130)$ and the southern $(n=112)$ Portuguese coasts. For five fish the type of fishing ground was unknown. The sample comprised more than three testes from each month and more than four testes from each $10-\mathrm{cm}$ fish size class found in the size span of male meagre on the Portuguese coast (up to $178 \mathrm{~cm}$ ). Exceptions to this were testes from the December to February period (when a single fish was sampled), testes from fish larger than $170 \mathrm{~cm}$ (two samples only) and testes from fish smaller than $30 \mathrm{~cm}$ (no sample).

The reproductive system of meagre males consists of a pair of elongated testes which lie within in the body cavity against the fish swimbladder. Upon dorsal observation, testes are rectangular in shape but variations occur between lozenge (middle part wider) and triangular (anterior part wider). The cross-section is generally triangular, with the base of the triangle fitting dorsally against the swimbladder and its tip oriented towards the belly. The surface of the testis is smooth and has two vascularized hili running along its dorsal surface. These hili fuse posteriorly to form a single sperm duct that opens to the genital pore.

The testes of mature meagre are creamy white to rosy between March and July, turning brownish thereafter. They appear full or half-full, filling the majority of the body cavity and easily rupturing upon handling or pressing from March to July, and become empty-

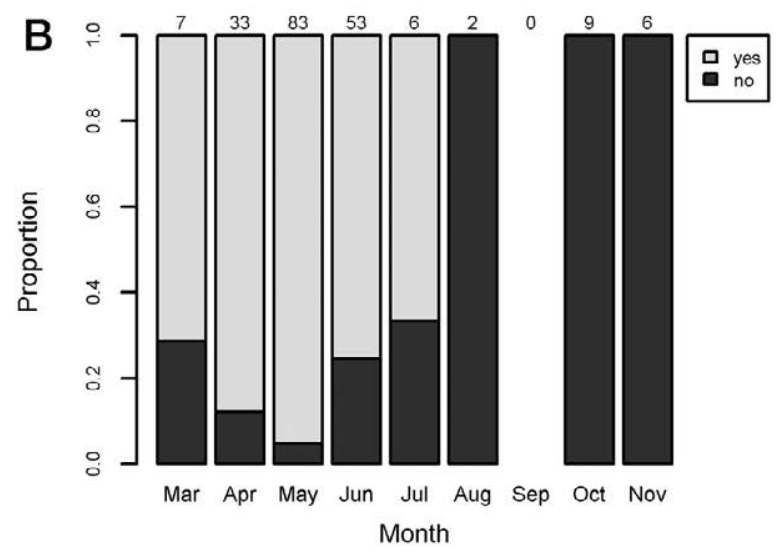

Fig. 1. - Monthly variations in the macroscopic appearance of testes of mature meagre ( $>80 \mathrm{~cm}$; Tixerant 1974$)$. $y$-axis represents the proportion of monthly samples that registered each feature. A, fullness; B, reaction to abdominal pressure. Numbers above bars are sample size. 

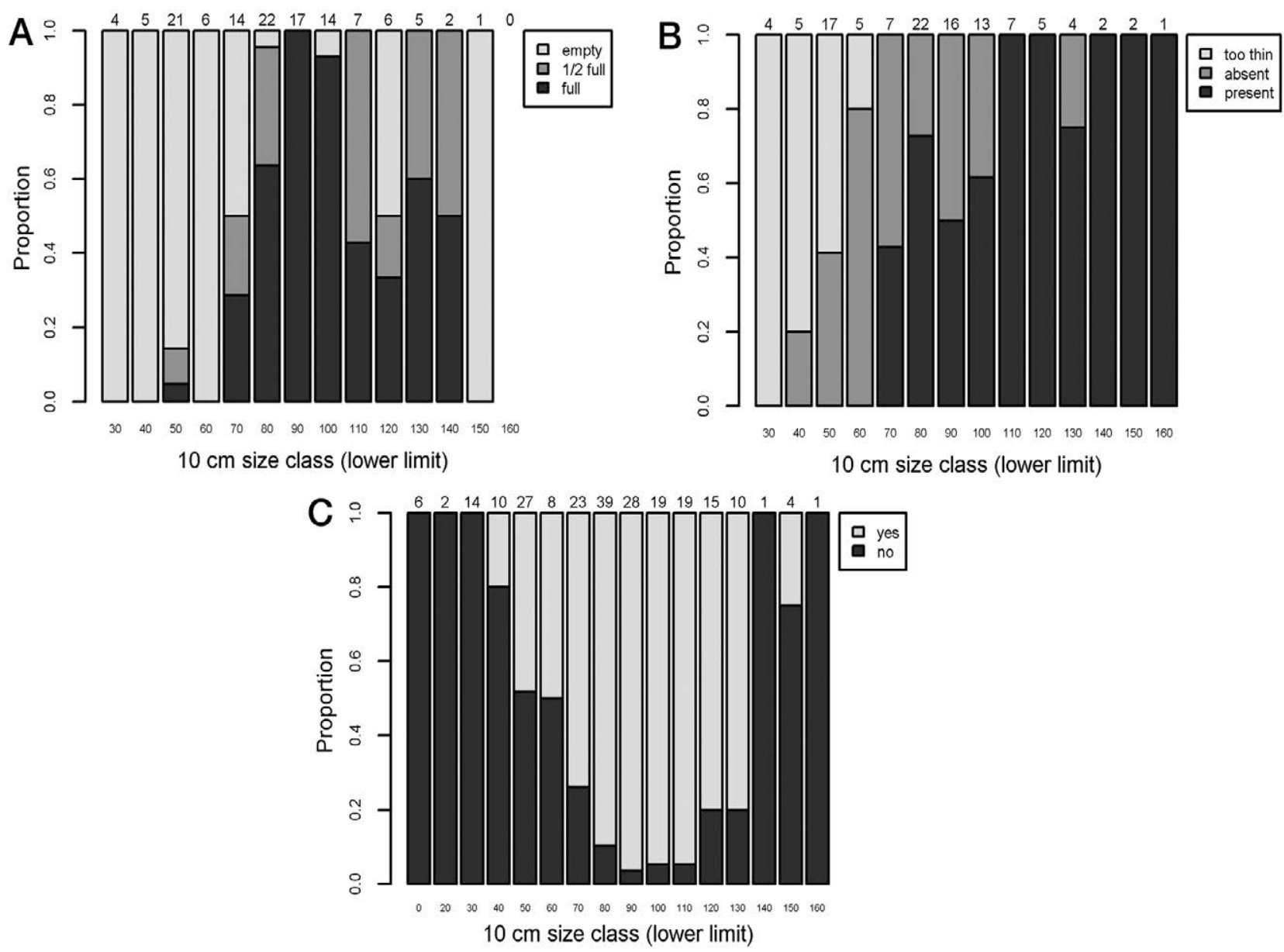

Fig. 2. - Size-related variations in the macroscopic appearance of testes of meagre during the putative spawning season (May and June). $y$-axis represents the proportion of samples that registered each feature. A, fullness; B, presence-absence of ventral striae ("too thin" indicates gonad so thin that identification of ventral striae could not be carried out); $\mathrm{C}$, reaction to abdominal pressure. Numbers above bars are sample size.

Table 2. - Gross anatomical grading system derived for the meagre testis. $\mathrm{W}_{\mathrm{g}}$, weight of gonad; TL, total length (mean \pm s.e.); A, age (mean \pm s.e.); M, month(s) of occurrence. GSI (\%) is calculated as (gonad weight/fish total weight)*100 (mean \pm s.e.).

\begin{tabular}{|c|c|c|}
\hline Anatomical class & Macroscopic features & Other notes \\
\hline 0 & $\begin{array}{l}\text { Very thin thread-like lobes (transparent and with barely any width or } \\
\text { thickness); sex of fish cannot be identified by naked eye. }\end{array}$ & $\begin{array}{l}\mathrm{W}_{\mathrm{g}} \approx 0 \mathrm{~g}(\mathrm{n}=6) \\
\mathrm{GSI}(\%), 0.04 \pm 0.00(\mathrm{n}=6) \\
\mathrm{TL}(\mathrm{cm}), 37.3 \pm 1.5(\mathrm{n}=6) \\
\text { A(years), 2.3 } 20.7(\mathrm{n}=3) \\
\text { M, June }\end{array}$ \\
\hline I & $\begin{array}{l}\text { White to rose or brown thread-like testes (translucent to opaque with } \\
\text { small but measurable width and thickness); reduced thickness makes the } \\
\text { observation of ventral striae and median cross-section very uncertain; no } \\
\text { reaction to abdominal pressure. }\end{array}$ & 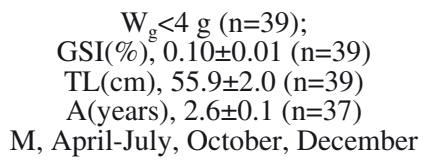 \\
\hline II & $\begin{array}{l}\text { White to rose opaque thread-like testes; median cross-section triangular or } \\
\text { domed; no conspicuous ventral striae; robust to handling; some sperm may } \\
\text { be present in the sperm duct; positive reaction to abdominal pressure but in } \\
\text { reduced amount. }\end{array}$ & $\begin{array}{l}1 \mathrm{~g}<\mathrm{W}_{\mathrm{g}}<34 \mathrm{~g}(\mathrm{n}=25) \\
\mathrm{GSI}(\%), 0.29 \pm 0.03(\mathrm{n}=25) \\
\mathrm{TL}(\mathrm{cm}), 64.0 \pm 2.2(\mathrm{n}=25) \\
\text { A(years }), 3.4 \pm 0.2(\mathrm{n}=19) \\
\text { M, April-July, October }\end{array}$ \\
\hline III & $\begin{array}{l}\text { White to rose testes, sometimes reddish with increased vascularization; testes } \\
\text { widen and increase in volume, becoming tubular in appearance; ventral striae } \\
\text { usually present; triangular median cross-section (I or II), very turgid, the } \\
\text { sperm duct occluded underneath the swollen surface; ruptures easily when } \\
\text { handled, tearing itself up under its own weight; positive reaction to abdominal } \\
\text { pressure, abundant semen throughout the gonad. }\end{array}$ & $\begin{array}{c}15 \mathrm{~g}<\mathrm{W}_{\mathrm{g}}<1420 \mathrm{~g}(\mathrm{n}=84) \\
\mathrm{GSI}(\%), 3.27 \pm 0.17(\mathrm{n}=84) \\
\text { TL }(\mathrm{cm}), 96.8 \pm 2.0(\mathrm{n}=83) \\
\text { A(years), 6.1 } \pm 0.2(\mathrm{n}=58) \\
\text { M, March-July }\end{array}$ \\
\hline IV & $\begin{array}{l}\text { Brownish white to dark brown testes with much-reduced volume; median } \\
\text { cross-section generally triangular with a pronounced proximal sulcus; } \\
\text { conspicuous ventral striae in larger individuals; flaccid appearance with } \\
\text { visible sperm duct; highly resistant to handling; some semen is visible in } \\
\text { sectioned testes, particularly when they are squeezed; little or no reaction to } \\
\text { abdominal pressure. }\end{array}$ & $\begin{array}{c}3 \mathrm{~g}<\mathrm{W}_{\mathrm{g}}<707 \mathrm{~g}(\mathrm{n}=89) \\
\mathrm{GSI}(\%), 0.60 \pm 0.06(\mathrm{n}=89) \\
\mathrm{TL}(\mathrm{cm}), 117.3 \pm 3.6(\mathrm{n}=88) \\
\text { A(years), 8.8 } \pm 0.8(\mathrm{n}=66) \\
\text { M, March, May-November }\end{array}$ \\
\hline
\end{tabular}




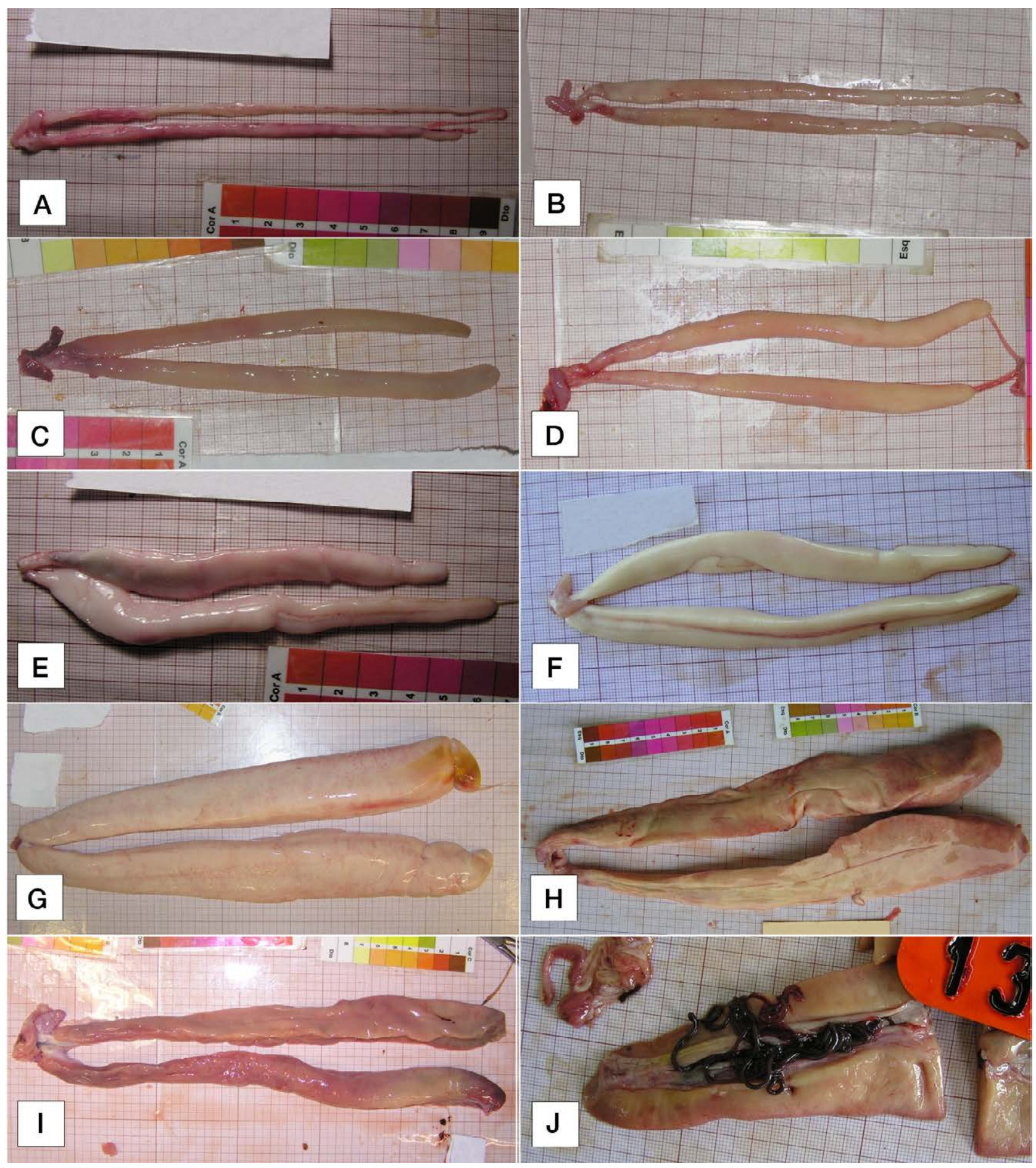

Fig. 3. - Macroscopic appearance of meagre male gonads [TL, total length in $\mathrm{cm}$; M, month of capture; P, Place of capture, Southern Coast (SC) or Tagus Estuary (TE); H, Histological stage]. A, anatomical class I [TL, 66; M, May; P, SC; H, developing]; B, anatomical class I [TL, 59; M, June; P, TE; H, spawning capable (virgin)]; C, anatomical class II [TL, 76; M, July; P, TE; H, developing]; D, anatomical class II [TL, 69; M, June; P, TE; H, spawning capable (virgin)]; E, anatomical class II [TL, 59; M, May; P, SC; H, spawning capable (mature)]; F, anatomical class III [TL, 59; M, June; P, TE; H, spawning capable (virgin)]; G, anatomical class III [TL, 100; M, May; P, TE; H, spawning capable (mature)]; H, anatomical class IV [TL, 148; M, June; P, SC; H, regressing]; I, anatomical class IV [TL, 144; M, October; P, SC; H, regenerating]; J, close-up of live parasites from genus Philometra.

looking and "rubberish" from August onwards (Fig. 1A). In spring and early summer the hili are generally occluded underneath the swollen dorsal surface, becoming visible thereafter. From May onwards many testes exhibit a marked proximal groove and ventral striae. Positive reaction to abdominal pressure increases from March (50\% of testes) to May (95\% of testes) and decreases thereafter (Fig. 1B). In late summer and autumn, residual milt is still observed in testis sections from fish showing no reaction to abdominal pressure, thus evidencing prolonged sperm storage in time. 
Within the putative spawning season (May and June) the macroscopic appearance of meagre testes changes markedly with size (Fig. 2). Fish $<40 \mathrm{~cm}$ all have very thin thread-like testes with barely any width. From 40 to $80 \mathrm{~cm}$ the testes widen and thicken rapidly but remain empty-looking and relatively thin in many fish (Fig. 2A, B). Over $80 \mathrm{~cm}$ no thin testes are observed and full to half-full gonads dominate (Fig. 2A). The testes of fish $<70 \mathrm{~cm}$ did not display ventral striae but these became apparent in fish $>70 \mathrm{~cm}$ and were present in all individuals above $110 \mathrm{~cm}$ (Fig. 2B). A positive reaction to abdominal pressure was not observed in fish below $40 \mathrm{~cm}$, but took place in $40 \%$ of individuals between 40 and $70 \mathrm{~cm}$, and in $85 \%$ of the fish larger than $70 \mathrm{~cm}$ (Fig. 2C).

Nematodes from the genus Philometra were found in the testes of 22 out of 101 males checked for these parasites. The parasites were most frequently observed along the sperm duct and were easier to observe when gonads are less turgid. All testes with parasites were sampled on the southern coast, where the monthly prevalence reached $91 \%$ in September.

Based on the previous macroscopic characteristics, the gross anatomical grading system derived for meagre testes is displayed in Table 2 and Figure 3.

\section{Histological classification scale}

A total of 136 testes were subjected to histological analysis. These testes were selected at random from the pool of testes collected each month, but the selection was constrained to the overarching objective of obtaining good coverage of a) the size classes sampled, b) the main macroscopic types observed in the field and c) the main fishing grounds for the species. The final sample included at least four testes from each $10-\mathrm{cm}$ fish size class between $40 \mathrm{~cm}$ and $170 \mathrm{~cm}$ and at least three testes from each month, with the exception of September $(n=1)$ and November through February $(n=0)$, when the meagre is scarce in Portuguese fisheries (Prista et al. 2008). Furthermore, testes from both estuarine $(n=87)$ and coastal $(n=31)$ fishing grounds and from both the western $(n=99)$ and the southern $(n=37)$ Portuguese coasts were represented. For 18 fish the fishing ground was unknown.

The internal structure of male testes is of lobular unrestricted type (sensu Parenti and Grier 2004). Active spermatogenesis occurs throughout the testis within spermatocysts that contain synchronously developing cell clones. Six developmental stages are present in male meagre germ epithelium: a) pri-
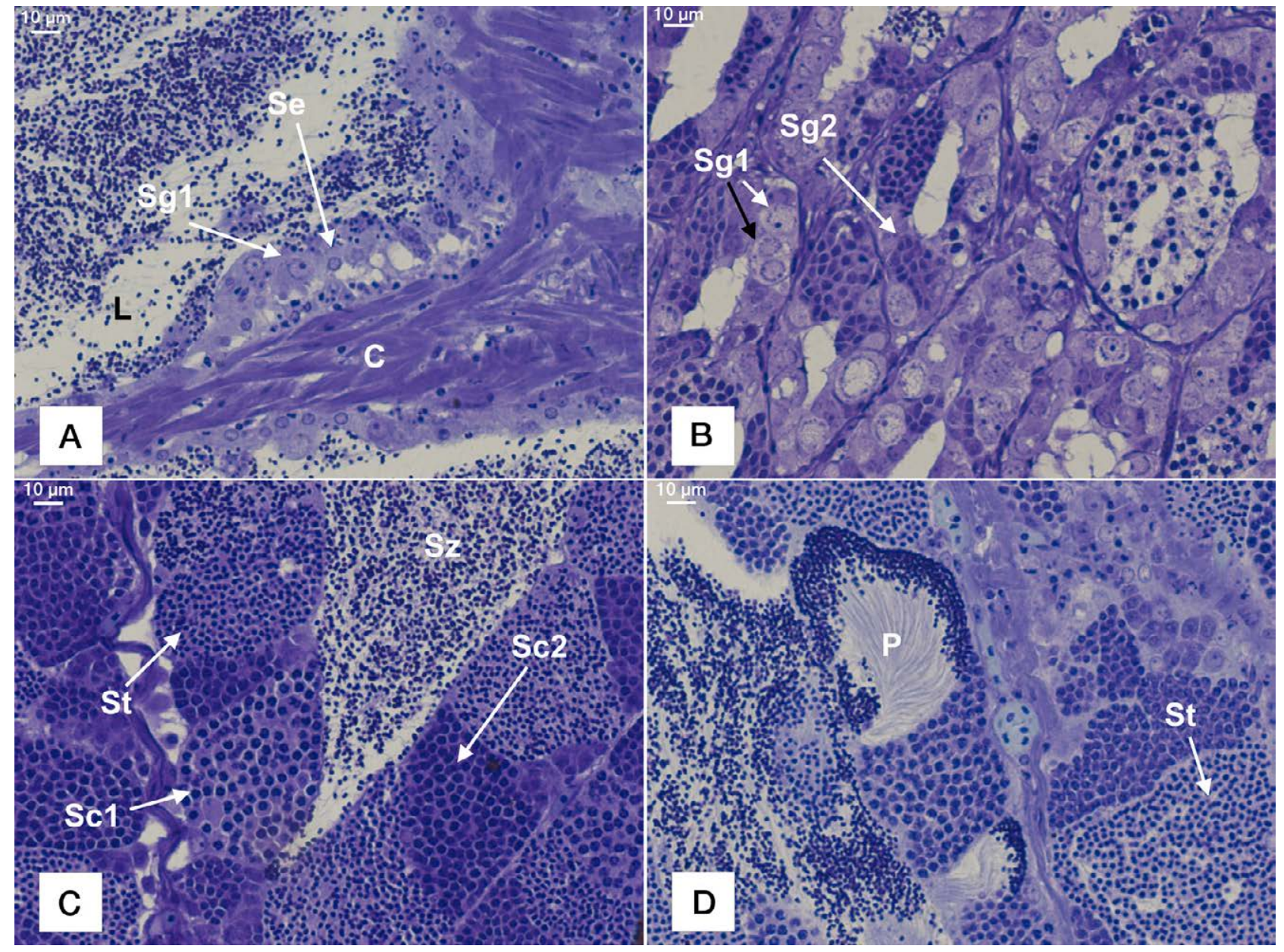

Fig. 4. - Histological stages of meagre spermatogenesis. A, primary spermatogonia ( $\mathrm{Sg} 1$ ); B, Sg1 and secondary spermatogonia ( $\mathrm{Sg} 2$ ). Black arrow, Sg1 in mitotic division; C, primary (Sc1) and secondary (Sc2) spermatocytes, spermatids (St) and spermatozoa (Sz); D, bursting St in "Parachute" form (P). Connective tissue (C), Lobule lumen (L), Sertoli cell (Se). Scale bar, $10 \mu \mathrm{m}, 400 \times$. 

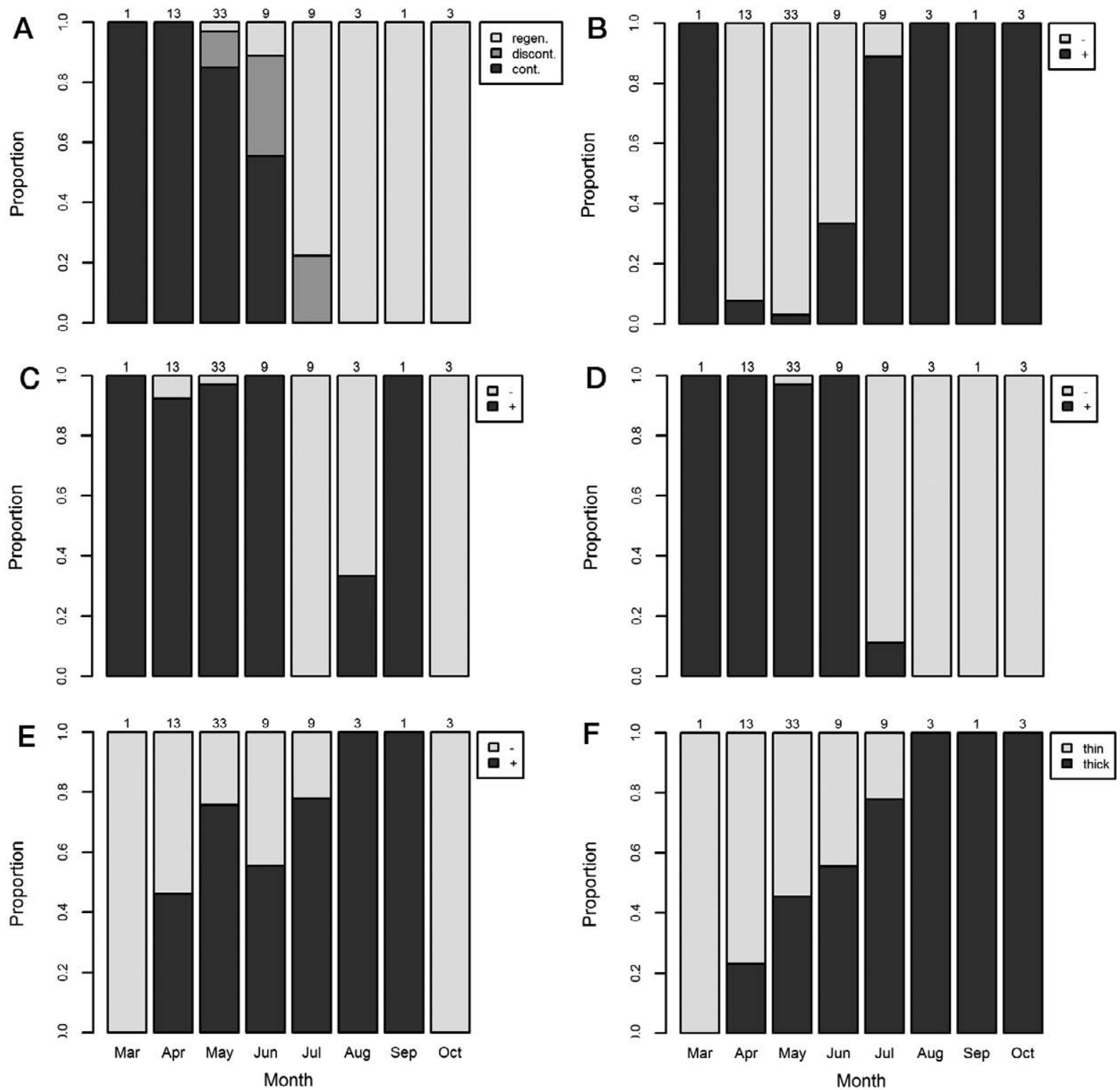

Fig. 5. - Month-related variations in the histologic characteristics of the testes of mature meagre (>80 cm; Tixerant 1974). $y$-axis represents the proportion of monthly samples that showed each feature. A, germinal epithelium structure (cont., continuous; discont, discontinous; regen., regenerated); B, primary spermatogonia; C, primary spermatocytes; D, spermatids; E, spermatozoa; F, tunica thickness. "+", abundant or very abundant, "-", not abundant or absent. Numbers above bars are sample size.

mary spermatogonia ( $\mathrm{Sg} 1)$, b) secondary spermatogonia (Sg2); c) primary spermatocytes (Sc1); d) secondary spermatocytes (Sc2); e) spermatids $(\mathrm{St})$; and $\mathrm{f}$ ) spermatozoa $(\mathrm{Sz})$.

Primary spermatogonia (Sg1) are oval-shaped cells, 7-22 $\mu \mathrm{m}$ in diameter, that appear isolated or in small groups. Both the nucleus and cytoplasm of $\mathrm{Sg} 1$ are slightly basophilic (light blue). The nucleus frequently occupies over $2 / 3$ of the cell surface and may have a conspicuous strongly basophilic nucleolus at the centre (dark blue). $\mathrm{Sg} 1$ are frequently accompanied by smaller Sertoli cells $\sim 4-7 \mu \mathrm{m}$ in diameter (Fig. 4A).

Secondary spermatogonia $(\mathrm{Sg} 2)$ are polygonal cells, 4-7 $\mu \mathrm{m}$ in diameter, that appear densely packed in nests with 8 to 35 cells. The nucleus has intermediate basophily (deep purple) and occupies nearly the entire cell. Cytoplasm is acidophilic and very reduced. No nucleoli are visible (Fig. 4B).
Primary spermatocytes (Sc1) are polygonal to round cells, 4-8 $\mu \mathrm{m}$ in diameter, that appear more loosely clustered (frequently over 50 cells) and in larger numbers than $\mathrm{Sg} 2$ (Fig. 4C). The nucleus of $\mathrm{Sc} 1$ is circular and strongly basophilic (dark blue), with no nucleolus visible. The cytoplasm has low basophily (light purple) and unlike $\mathrm{Sg} 2$ is clearly distinguishable under light microscopy.

Secondary spermatocytes $(\mathrm{Sc} 2)$ are similar in appearance and numbers to $\mathrm{Sc} 1$ but smaller $(3-6 \mu \mathrm{m})$, more basophilic (both nucleus and cytoplasm) and more densely packed (Fig. 4C). Sc2 are a relatively brief developmental stage that are abundant only in $30 \%$ of spawning-capable individuals.

Spermatids (St) are markedly smaller than the previous spermatogenic stages, their nucleus remaining strongly basophilic and the cytoplasm has intermediate basophily. Their overall size $(2-4 \mu \mathrm{m})$ is low compared 
with Sc2. They appear in very dense nests that may contain several hundred cells (Fig. 4C, D).

Spermatozoa $(\mathrm{Sz})$ first appear with their heads and tails aligned within recently burst St cysts in "parachute" form (Fig. 4D). Their heads are tiny (1-3 $\mu \mathrm{m})$ and strongly basophilic (dark blue), their tails being long and mildly basophilic (light purple). During spawning, they are released to the lumen of the lobules where they form very dense aggregations (Fig. 4C).
The testes of mature meagres display a tubular appearance throughout the year, active spermatogenesis taking place from March to June. During this period $\mathrm{Sg} 1$ are rare and the GE changes from continuous to discontinuous and then again to continuous but with $\mathrm{Sg} 1$ only (=regenerated) (Fig. 5A) suffering significant developmental changes. Among these are a rapid reduction in $\mathrm{Sg} 1$ and $\mathrm{Sg} 2$ (Fig. 5B) that gives rise to sustained high levels of Sc1 and St and abundant $\mathrm{Sz}$

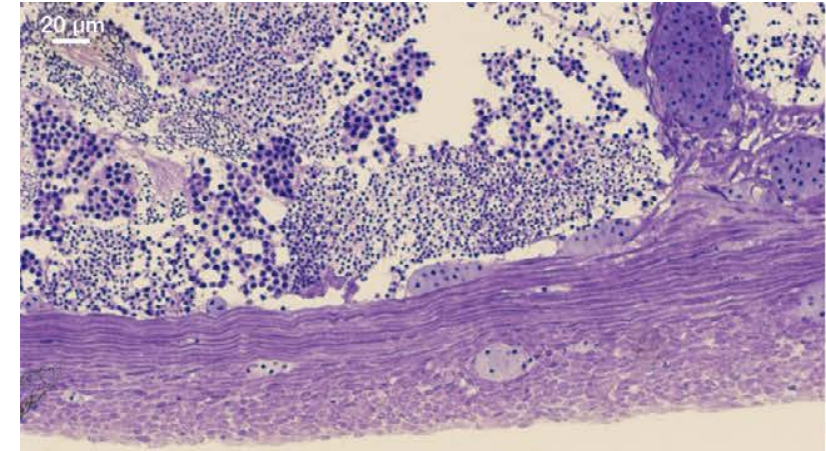

A
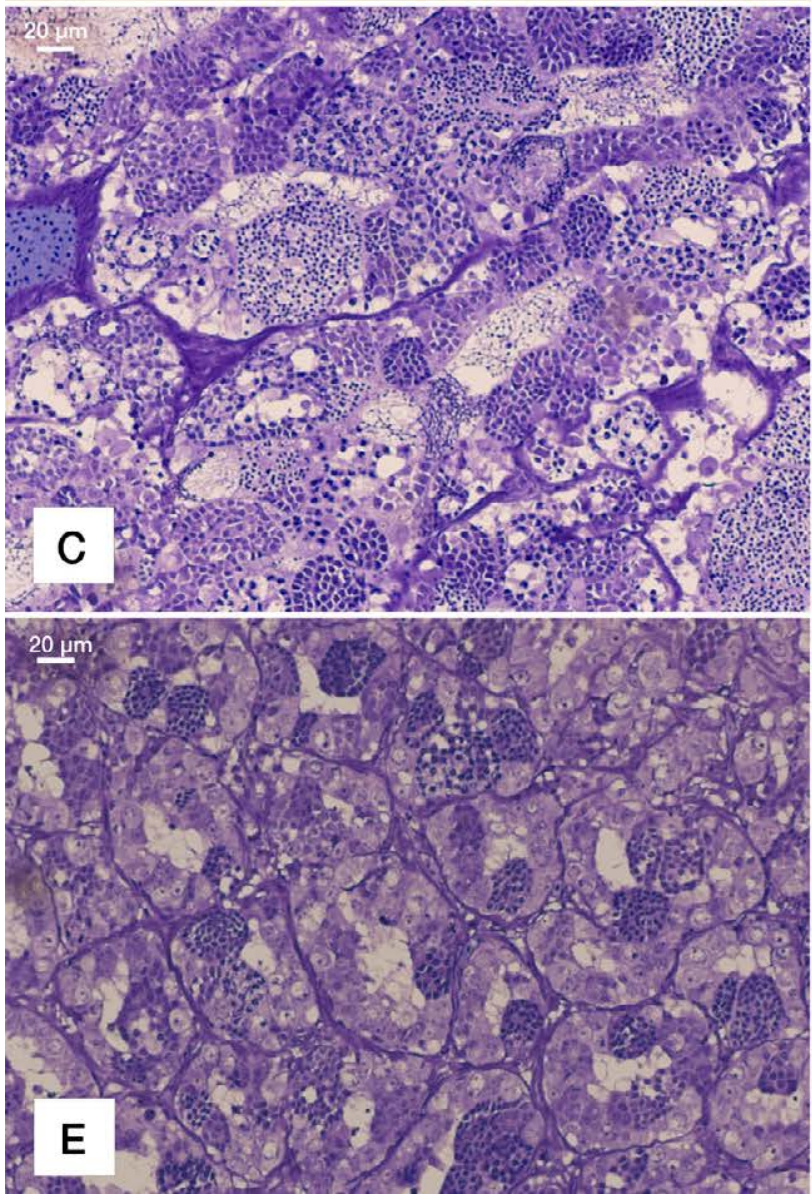
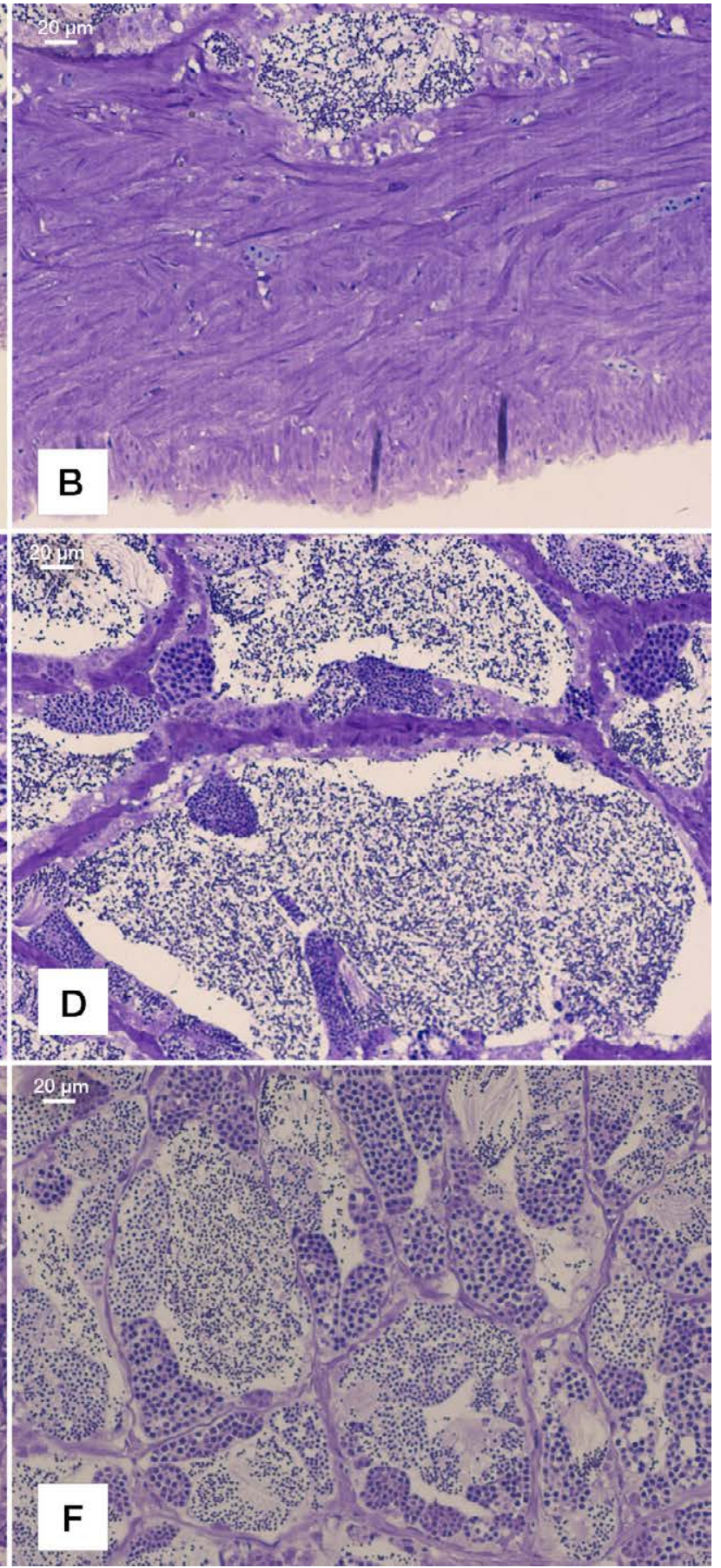

Fig. 6. - Details of month-related and size-related variability in the testes of meagre [TL, total length in $\mathrm{cm}$; M, month of capture; $\mathrm{P}$, place of capture, southern coast (SC) or Tagus Estuary (TE); H, Histological stage]. A, thin wall during spawning months [TL, 140; M, April; P, SC; $\mathrm{H}$, spawning-capable]; $\mathrm{B}$, thick wall characteristic of post-spawning [TL, 148; M, June; P, SC; H, regressing]; C, thin connective tissue forming the lobular walls [TL, 144; M, March; P, SC; H, developing]; D, thickened connective tissue [TL, 177; M, June; P, SC; H, regressing]; E, compact appearance with no sperm present [TL, 56; M, June; P, TE; H, developing]; F, compact appearance with sperm present [TL, 44; M, June; P, TE; H, spawning-capable]. Scale bar, $20 \mu \mathrm{m}, 200 \times$. 

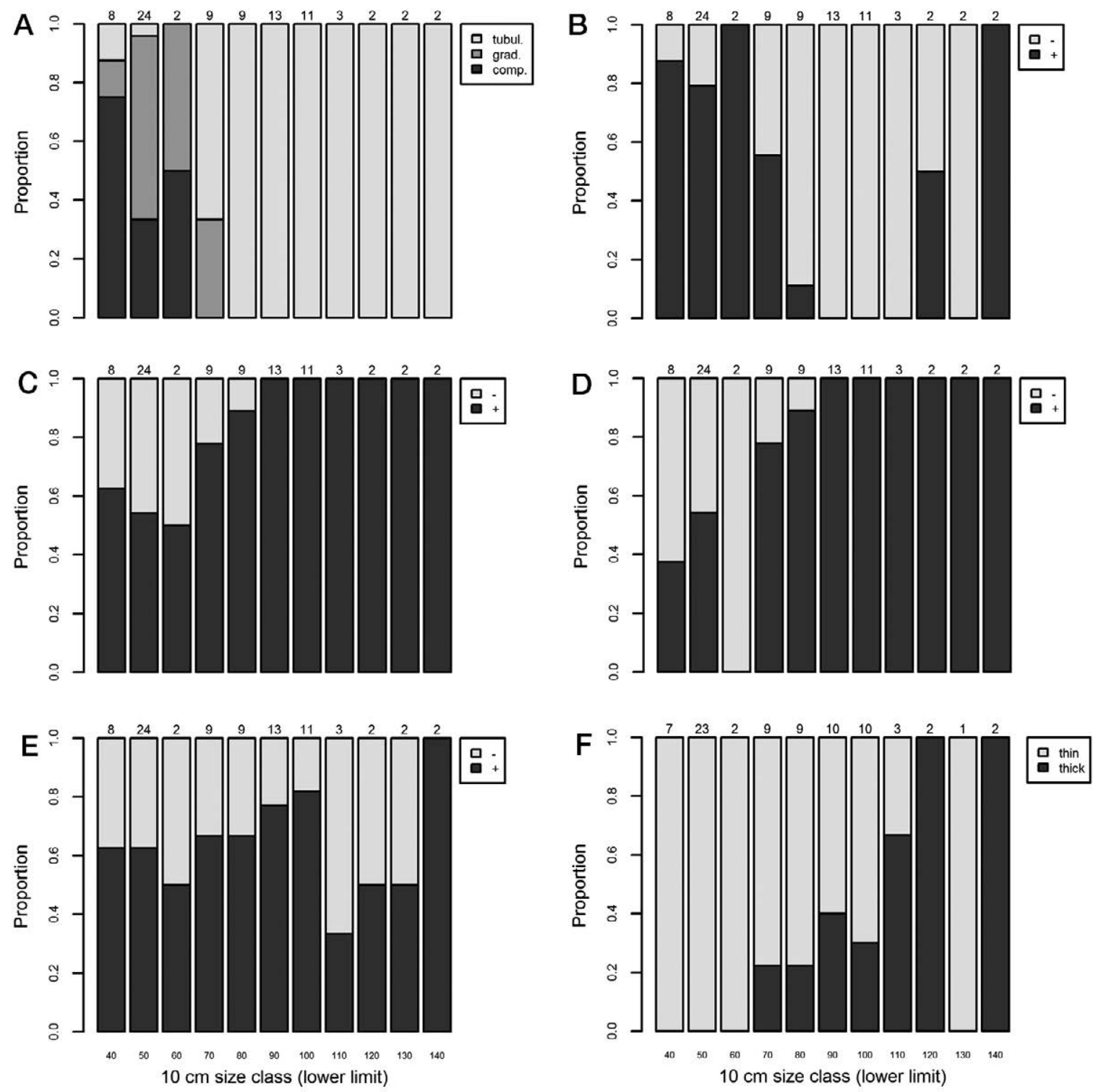

Fig. 7. - Size-related variations in the histologic characteristics of the testes of meagre during its putative spawning season (May and June). $y$-axis represents the proportion of samples that registered each feature. A, Overall testis structure (comp., compact; grad, gradient (compact at periphery, tubular at core); tubul, tubular); B, primary spermatogonia; C, primary spermatocytes; D, spermatids; E, spermatozoa; F, tunica thickness. "+", abundant or very abundant; "“”, not abundant or absent. Numbers above bars are sample size.

both in the outer and inner lobules (Fig. 5C-E). As the season progresses, the testis wall (tunica albuginea) and lobule connective tissue thicken (Figs 5F and 6A-D) and $\mathrm{Sg} 1$ start to increase abundance, lining up the naked lobule walls (Fig. 5B). From July onwards, testes displaying $\mathrm{Sg} 2, \mathrm{Sc} 1, \mathrm{Sc} 2$ and $\mathrm{St}$ become increasingly rare, and $\mathrm{Sg} 1$ proliferate forming cords that line up the internal walls of the lobules, giving them a characteristic regenerated appearance (Fig. 5A). Sz are still abundant but now concentrated mostly in the inner lobules and sperm duct, becoming more rare in peripheral lobules (Fig. 5E).

The peripheral lobules of most fish $<70 \mathrm{~cm}$ are generally compact, with relatively narrow lumina and a GE where $\mathrm{Sg} 1$ and $\mathrm{Sg} 2$ are abundant alongside more developed spermatogenic stages (Fig. 7A, B). On the other hand, the testes of fish $>80 \mathrm{~cm}$ all have a tubular appearance, with GE continuous to discontinuous, dominated by Sc1, St and Sz (Fig. 7C-E). Thick testis walls appear only in fish $>70 \mathrm{~cm}$ (Fig. 7F). Interestingly, some fish smaller than $50 \mathrm{~cm}$ already show signs of spermatogenic activity, displaying small inner lobules filled with $\mathrm{Sz}$ even if their testes are relatively small (Figs 6F and 7E). Despite the ongoing spawning season, it was noticed that some large fish sampled from coastal marine grounds already evidenced some signs of regeneration, namely $\mathrm{Sg} 1$ proliferation (Fig. 7B).

Based on the previous characteristics the histological development of the meagre testis was divided into five main phases (Fig. 8, Table 3). A subdivision of testes in spawning-capable phase into "spawning capable (virgin)" and "spawning capable (mature)" warrants a separation between younger and smaller spawning-capable fish that still show signs of immaturity (namely abundant $\mathrm{Sg} 1$ and $\mathrm{Sg} 2$ ) and older and larger fish that do not display such signs (Table 3 ). 

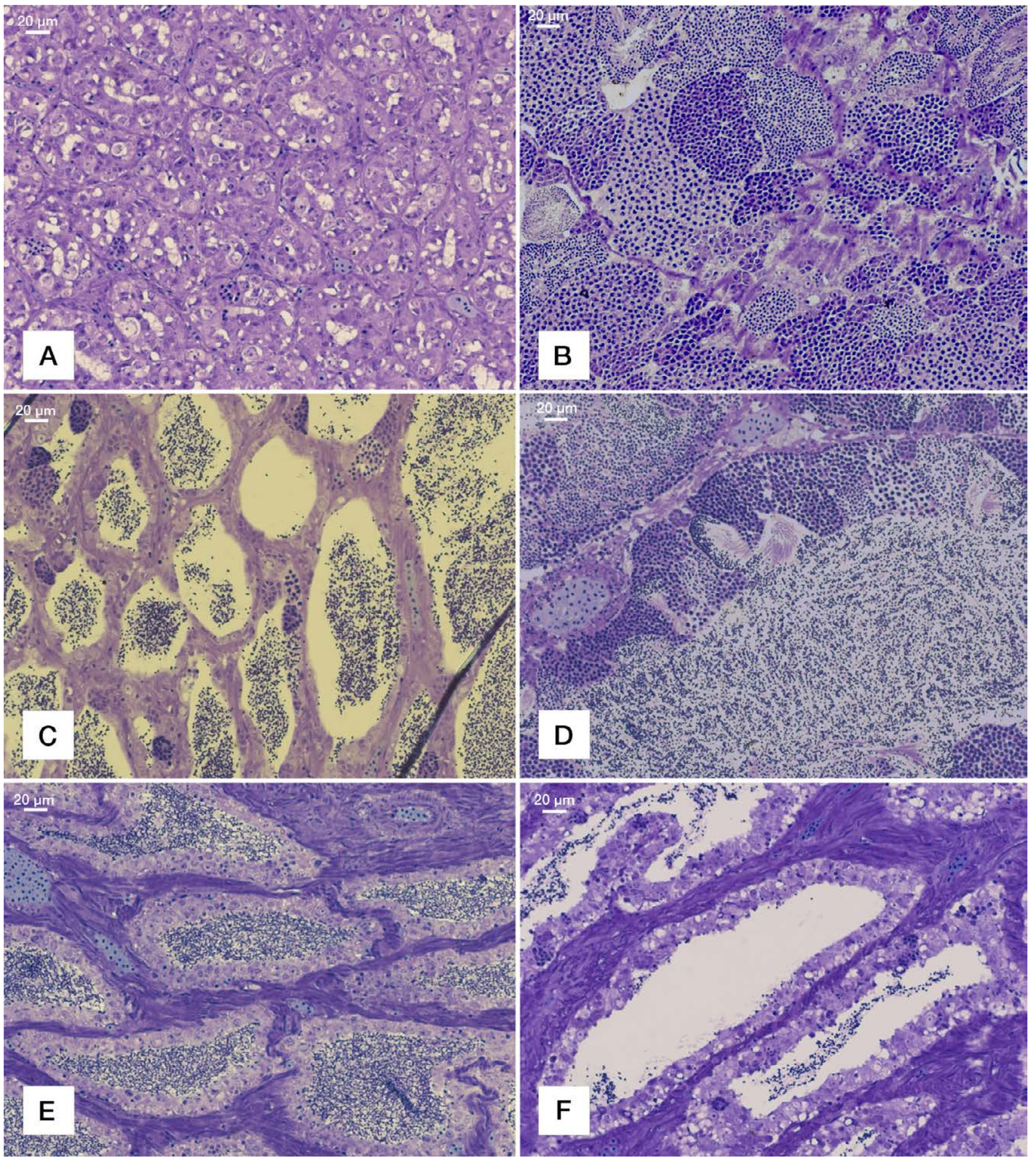

Fig. 8. - Histological phases of the meagre reproductive cycle. [TL, total length in $\mathrm{cm}$; M, month of capture; P, place of capture, southern coast (SC) or Tagus Estuary (TE); Ma, Macroscopical phase]. A, immature [TL, 51; M, March; P, TE; Ma, not determined]; B, developing [TL, 70; M, April; P, TE; Ma, not determined]; C, spawning-capable (virgin) [TL, 59; M, June; P, TE; Ma, Anatomical class I]; D, spawning-capable (mature) [TL, 100; M, May; P, TE; Ma, Anatomical class III]; E, regressing [TL, 127; M, September; P, SC; Ma, Anatomical class IV]; F, regenerating [TL, 144; M, October; P, SC; Ma, Anatomical class IV]. Scale bar, $20 \mu \mathrm{m}, 200 \times$.

\section{Histological corroboration of the anatomical scale}

A comparison of the results obtained in 104 testes subjected to both macroscopic and histologic analysis is presented in Table 4. A good correspondence was found between anatomical class 0 and histological phase immature, between the anatomical class II and the histological spawning-capable (virgin) phase, be- tween anatomical class III and the histological spawning-capable (mature) phase, and between anatomical class IV and the histological regressing phase, with 11\%-16\% error in one-to-one histological assignment of these anatomical classes. Testes classified as anatomical class I were found to be in histological developing phase or in spawning capable (virgin) phase, with a lower proportion being regressing or immature 
Table 3. - Histological grading system of the meagre testis. Sg, spermatogonia; Sc1, primary spermatocytes; Sc2, secondary spermatocytes; St, spermatids; Sz, spermatozoa; GE, germinal epithelium; $\mathrm{W}_{\mathrm{g}}$, weight of gonad; GSI, Gonadosomatic index (calculated as in Table 2; mean \pm s.e.); TL, total length (mean \pm s.e.); A, age (mean \pm s.e.); M, month(s) of occurrence.

\begin{tabular}{ll}
\hline Phase & \multicolumn{1}{c}{ Main Histological features } \\
\hline Immature & Compact appearance; only Sg1 and Sg2 present. \\
& \\
Developing & $\begin{array}{l}\text { Thin tunica; Lobular appearance (small compact lobules in developing } \\
\text { virgins); continuous GE with spermatocysts in all stages; little or no Sz. }\end{array}$ \\
& $\begin{array}{l}\text { Thin to intermediate width tunica; lobular appearance; wider lobules, very } \\
\text { elongated in internal regions; GE of lobules ranging from continuous to } \\
\text { totally discontinuous; Sc1 and St predominant; Sz very abundant in the } \\
\text { internal regions and frequently also at periphery. }\end{array}$
\end{tabular}

Spawning capable (virgin): Sg1 and Sg2 present and abundant;

Spawning capable (mature): Sg1 absent; GE progresses from continuous in all lobules (early subphase) to discontinuous in all lobules (late subphase); Sc1 are present in large amounts (early subphase) and decrease over time, becoming rare (late subphase); St present in large amounts (early subphase) and decreasing to moderate amounts (late phase); a few late subphase individuals may show signs of $\mathrm{Sg} 1$ proliferation during the late subphase.

Regressing Lobular appearance; intermediate to thick tunica; wide lobules; GE increasingly continuous composed of proliferating Sg1 (in cords) and a few scattered Sc1 and St; Sz may still be abundant in internal lobules and sperm duct, but decrease in abundance towards periphery.

Regenerating Lobular appearance. Sg1 and Sg2 proliferate throughout the testis, thickening the GE and thinning the lobular lumen; later stages of spermatogenesis may be present but in reduced amounts $(\mathrm{Sc} 1, \mathrm{Sc} 2, \mathrm{St})$; no Sz. Tunica still thick, becoming thinner.

Other notes

$$
\begin{aligned}
& \mathrm{W}_{\mathrm{g}}<1 \mathrm{~g}(\mathrm{n}=4) \\
& \begin{aligned}
& W_{\mathrm{g}}<1 \mathrm{~g}(\mathrm{n}=4) \\
& \mathrm{GSI}(\%), 0.07 \pm 0.01 \quad(\mathrm{n}=4)
\end{aligned} \\
& \text { TL }(\mathrm{cm}), 48.5 \pm 2.0(\mathrm{n}=4) \\
& \text { A(years), 3.0 } 0.0 \quad(n=4) \\
& \text { M, March, June } \\
& \mathrm{W}_{\mathrm{g}}<157 \mathrm{~g}(\mathrm{n}=26) \\
& \operatorname{GSI}(\%), 0.36 \pm 0.11 \quad(\mathrm{n}=26) \\
& \text { TL }(\mathrm{cm}), 67.6 \pm 4.4(\mathrm{n}=27) \\
& \text { A(years), } 3.9 \pm 0.4(n=27) \\
& \text { M, March-July } \\
& \text { Spawning capable (all) } \\
& 1<\mathrm{W}_{\mathrm{g}}<1422 \mathrm{~g}(\mathrm{n}=77) \\
& \operatorname{GSI}(\%), 2.19 \pm 0.21(\mathrm{n}=77) \\
& \text { TL }(\mathrm{cm}), 85.7 \pm 2.7(\mathrm{n}=79) \\
& \text { A(years), 5.0 } \pm 0.2(n=78) \\
& \text { M, April-July } \\
& \text { Spawning capable (virgin) } \\
& 1<\mathrm{W}_{\mathrm{g}}<173 \mathrm{~g}(\mathrm{n}=34) \\
& \operatorname{GSI}(\%), 0.60 \pm 0.10(\mathrm{n}=34) \\
& \text { TL }(\mathrm{cm}), 59.5 \pm 3.1 \quad(\mathrm{n}=34) \\
& \text { A (years), 3.6 } \pm 0.2(n=33) \\
& \text { M, April-July } \\
& \text { Spawning capable (mature) } \\
& 58<\mathrm{W}_{\mathrm{g}}<1422 \mathrm{~g}(\mathrm{n}=43) \\
& \operatorname{GSI}(\%), 3.45 \pm 0.22(\mathrm{n}=43 \\
& \text { TL }(\mathrm{cm}), 100.9 \pm 2.1 \quad(\mathrm{n}=45) \\
& \text { A(years), 6.0 } \pm 0.2(n=45) \\
& \text { M, April-June } \\
& 1<\mathrm{W}_{\mathrm{g}}<412 \mathrm{~g}(n=23) \\
& \operatorname{GSI}(\%), 0.51 \pm 0.09(\mathrm{n}=23) \\
& \text { TL(cm), 109.7 } \pm 8.4(\mathrm{n}=24) \\
& \text { A(years), 9.5 } \pm 1.5(n=22) \\
& \text { M, May-October } \\
& 86<\mathrm{W}_{\mathrm{g}}<90 \mathrm{~g}(\mathrm{n}=2) \\
& \text { GSI }(\%), 0.35 \pm 0.01(\mathrm{n}=2) \\
& \text { TL }(\mathrm{cm}), 143.0 \pm 1.5(\mathrm{n}=2) \\
& \text { A(years), } 12(n=1) \\
& \mathrm{M}, \text { October }
\end{aligned}
$$

\begin{tabular}{|c|c|c|}
\hline \multirow[b]{2}{*}{ Histological phase } & \multicolumn{2}{|c|}{ Milt upon abdominal pressure? } \\
\hline & No & Yes \\
\hline Immature & 2 & 0 \\
\hline Developing & 5 & 0 \\
\hline Spawning-capable (virgin) & 14 & 14 \\
\hline Spawning-capable (mature) & 1 & 29 \\
\hline Regressing & 5 & 1 \\
\hline Regenerating & 0 & 0 \\
\hline
\end{tabular}

(Table 4). Alongside the evidence obtained for anatomical class II and the covariate data displayed in Tables 2 and 3 , the latter results indicate that smaller and younger meagres with inconspicuous testes and histological signs of immaturity already display a seasonal maturation cycle in testes development with minor spermatozoa production.

Gross anatomical scales and milt production are frequently used to assess size-at-maturity during the spawning season. Restricting the results displayed in Table 4 to the peak spawning season (May and June) indicates that all testes assigned to anatomical classes II, III and IV corresponded to individuals that were either in the spawning-capable phase or in the regressing phase and can therefore be safely assumed to be mature. In anatomical class I, one individual (7\%) was immature and five individuals $(33 \%)$ were still in the developing phase during the peak spawning season, being unlikely to spawn in the current season. This finding indicates that some error may be introduced into maturity ogives if class I individuals are assumed mature without a complementary histological analysis. The probability of being mature while expressing milt was $100 \%$ but $50 \%$ of spawning-capable virgins and nearly all regressing fish did not express milt and could
Table 4 - Histological corroboration of the gross anatomical scale. Numbers displayed are percentages of column totals.

\begin{tabular}{lccccc}
\hline \multirow{2}{*}{ Histological phase } & \multicolumn{5}{c}{ Anatomical class } \\
& 0 & I & II & III & IV \\
& $(\mathrm{n}=1)$ & $(\mathrm{n}=17)$ & $(\mathrm{n}=18)$ & $(\mathrm{n}=43)$ & $(\mathrm{n}=25)$ \\
\hline Immature & 100 & 6 & - & - & - \\
Developing & - & 47 & 11 & - & 8 \\
Spawning-capable (virgin) & - & 35 & 89 & 16 & 4 \\
Spawning-capable (mature) $)$ & - & - & - & 84 & - \\
Regressing & - & 12 & - & - & 84 \\
Regenerating & - & - & - & - & 4 \\
\hline
\end{tabular}

Table 5. - Meagre reaction to abdominal pressure during peak spawning season. Numbers are specimens.

therefore be classified as immature in analyses that consider milt expression to be the only maturity indicator (Table 5). 


\section{DISCUSSION}

This paper presents the first detailed study of the male reproductive characteristics of wild Argyrosomus spp. across the species size span. It is also one of the few available studies detailing testis histology of a large-sized sciaenid (but see Grier et al. 1987) and, to our knowledge the first detailed attempt at corroborating a gross anatomical scale of male gonads with histological evidence.

The testes of mature meagres belong to the unrestricted spermatogonial type, with spermatogonia appearing in both distal (peripheral) and proximal (core) regions. However, in the testes of developing young fish the density of spermatogonia and Sertoli cells appears to be larger in peripheral regions than in proximal regions. Almeida et al. (2008) described the existence of a germinative zone at the periphery of Gadus morhua testes where higher spermatogonial concentrations took place. Grier et al. (1987) described higher concentrations of spermatogonia in the recovering testes of Sciaenops ocellatus. Both authors suggest that these spermatogonia concentrations are linked to testis enlargement through lobule elongation. Other authors have considered the possibility that these asymmetries could reflect an intermediate form of (partially) restricted testis organization (Schulz et al. 2011). Our sample size of developing mature fish was low but it confirms that in meagre some highly dense nests of spermatogonia and Sertoli cells do take place in more peripheral lobules, thus building evidence towards the participation of these cells in testis enlargement.

Spermatogenesis is the process whereby diploid spermatogonia proliferate and evolve to form haploid spermatozoa (Schulz et al. 2011). Similar to other fish, the basic functional units of the meagre testes are the spermatocysts, i.e. envelopes of dynamic Sertoli cells that harbour clusters of synchronously developing cell clones (Schulz et al. 2011). Spermatocyst development is asynchronous throughout the testis with different spermatocyst development stages being present in each lobule during the developing and spawning-capable phases. Similar to descriptions of other species (e.g. Grier et al. 1987) and the currently accepted conceptual models for teleost testis development (Brown-Peterson et al. 2011, Schulz et al. 2011), in meagre the germinal epithelium is subjected to marked seasonal variation. Mitotic proliferation of primary spermatogonia takes place right after (sometimes overlapping) the end of the spawning period (Fig. 4A). Then secondary spermatogonia ( $\mathrm{Sg} 2$ ) evolve from mitotic divisions of scattered primary spermatogonia (Sg1) (Fig. 4B) and undergo the first meiotic division to form primary spermatocytes $(\mathrm{Sc} 1) . \mathrm{Sc} 1$ are the most frequent stage of spermatogenesis (Fig. 4C), probably due to the long duration of the first meiotic prophase (Schulz et al. 2011). Final "parachute" formation of spermatozoa has been reported in Otolithes ruber, Liza carinata and Percaflavescens but does not appear to be a widespread phenomenon among teleosts (Dadzie and Abou-Seedo 2004). Overall, the maximum potential annual sperm production of large mature meagre appears to be fully determined at the end of the developing phase, since from then onwards spermatogonia become rare in mature individuals as a result of their evolution through spermatogenesis to form spermatozoa (Grier 2002). We predict that annual sperm production in meagre likely results from interactions between size and age, since large spawning capable fish can carry testes with more than 10 times the weight of those from smaller spawning capable fish. Further studies on the histology of this species should help to clarify such issues.

Historically, macroscopic classifications of gonad development have constituted the methodological basis for most reproductive studies of fish, particularly in male reproduction. This is the case of meagre and other large-sized sciaenids, in which anatomical scales with four levels (Hermas 1995), five levels (Tixerant 1974), six levels (Abou Shabana et al. 2012), seven levels (Griffiths 1996) and eight levels (Farmer 2008, Gil et al. 2013) have been previously used in describing the male reproductive cycle. In such species, the few studies that used histology sections to assess reproductive parameters did not detail the histological results (e.g. Murphy and Taylor 1989, 1990), were based on aquaculture observations of small young fish (Gil et al. 2013), used a very limited sample size ( $<30$ individuals; Abou Shabana et al. 2012) or did not report on the macroscopic appearance of male gonads (Grier et al. 1987). To our knowledge, the only comprehensive studies that reported on the histological features of meagre males were carried out with essentially juvenile fish (fish up to $84 \mathrm{~cm}$ in length and 62 months old) in aquaculture facilities and also did not provide information on macroscopic versus histological correlations of meagre testis (Schiavone et al. 2012, Gil et al. 2013).

The meagre results underscore the importance of carrying out validation studies of the gross anatomical scales before using them to routinely assess male reproductive status or establish management measures (Hunter and Maciewicz 2003). They also demonstrate how an objective gross anatomical scale can be developed from raw observational data using semiquantitative graphical displays (Figs 1 and 2). Such displays helped to highlight objective characteristics to be used in the anatomical scale and the success of the final validation success might be explained by that in part. We have also shown that the final gross anatomical scale adopted for meagre provided a relatively reliable proxy for the main reproductive development phases of male gonads. Specifically, anatomical classes II and III both correspond to spawning-capable fish and can therefore be used to assess spawning season and determine size-at-maturity. Whether or not classes I and II should be fully considered mature in building maturity ogives used for advising managers is left open to discussion, since the reproductive output of spawning-capable virgins is likely much lower than that of adult fish. Additionally, we have shown that gross anatomical class IV adequately reflects the end of spawning season (regressing phase). We did not find a gross macroscopically level that accurately reflected the histological developing phase, probably because we did not find a fishery targeting such large 
individuals in the late autumn and winter months. Most importantly, we have shown that, though relatively accurate maturity data on males can be obtained from the use of gross anatomical scales, these are not objective enough and precise enough to resolve all the vital information for management that is provided by concurrent histological results. The latter is particularly noticeable in the significant proportion of small-sized fish that can be classified as reproductively active by some macroscopic criteria (e.g. milt extrusion) but not by all criteria (e.g. cross-section shape) and in the fact that some testis classified as spawning-capable showed a quite distinct external appearance, gonad weight and gonadosomatic index (GSI) level.

Gross anatomical grading systems can be improved by reducing the number of classes and focusing on the most reliable characters (Hunter and Macewicz 2003). However, even in simpler systems, a frequent flaw is the confounding of fish that have just spawned and have regressing gonads with fish that are developing and yet to attain first maturity. In meagre males, we found that anatomical class IV rightly classifies most gonads as regressing with little overlap with developing fish. However, we note that ca. 3/4 of our samples were collected at the onset or during the fish spawning season, a time of the year that maximizes the classification success of anatomical grading systems (Hunter and Macewicz 2003, Lowerre-Barbieri et al. 2011). Another cause of concern with anatomical scales is the presence of skip spawners, i.e. fish that have already matured once but fail to spawn in a specific year. Existing knowledge of skip-spawning in male fish is very limited but these are generally identified as fish large enough to be mature that, during the spawning season, have a low GSI, a thick testicular wall and no sign of spermatogenic activity (Rideout and Tomkiewicz 2011). In our study, we found two mature fish $(>80 \mathrm{~cm})$ caught in the spawning season that had a thick wall and low GSI $(<1 \%)$. Both these fish showed signs of active spermatogenesis, namely a few (but not many) spermatocysts in multiple developmental stages. Consequently, they likely belonged to fish at the end of the spawning season (regressing) and not to skip spawners. Even so, we caution that our samples are not fishery-independent and that we cannot exclude the possibility that some skip-spawning fish may spend the spawning season in areas away from the main fishing grounds (González-Quirós et al. 2011).

To date, the large sciaenid fisheries literature has frequently reported smaller size-at-maturity $\left(\mathrm{L}_{50}\right)$ in males than in females, with discrepancies ranging between a few $\mathrm{cm}$ and nearly $30 \mathrm{~cm}$ (e.g. Murphy and Taylor 1989, 1990, Nieland and Wilson 1993, Wilson and Nieland 1994, Griffiths 1996, 1997). Some of these studies have used milt extrusion as indicative of maturity (e.g. Wilson and Nieland 1994), others have applied gross anatomical scales (Hermas 1995, Griffiths 1996, 1997), and yet others have carried out histological analysis of gonads, considering sperm presence as indicative of maturity and not including a subclass of first maturing spawning-capable fish (e.g. Murphy and Taylor 1990). We have shown that milt expression is an unreliable indicator of maturity in meagre, because it wrongly classifies as immature $50 \%$ of spawningcapable virgins and $83 \%$ of testes in regressing condition (Table 5). This situation probably extends to males of other sciaenids and warns against the use of ripeness as a maturity indicator in building maturity ogives in sciaenid species. Implicitly acknowledging some of the problems associated with categorizing very small fish as mature, Griffiths (1997) categorized some small milt-extruding males of Argyrosomus inodorus as immature based on supplemental anatomical criteria, namely the presence of disproportionally small testes and the absence of drumming muscles. This author came to assume that these fish made a low contribution to the total reproductive output of the population. As for Argyrosomus regius, neither Tixerant (1974) nor Hermas (1995) reported mature males $<70 \mathrm{~cm}$, but in the Gulf of Cadiz González-Quirós et al. (2011) noted that $26 \%$ of male meagres $<70 \mathrm{~cm}$ were mature and suggested such precocious maturation could represent a reproductive strategy (e.g. sneaker small-sized males) or be revealing of different fish populations with lower size-at-maturity (e.g. Farmer 2008). While researching first maturation of aquacultured meagre, Schiavone et al. (2012) found puberty to be reached at two years and $26.8 \mathrm{~cm}(920 \mathrm{~g})$ with still increasing GSI and hormone levels and Gil et al. (2013) determined the male length and age at $50 \%$ maturity to be $49.3 \mathrm{~cm}$ and 32.3 months, respectively. The growth rates of these fish were markedly different from those of wild populations (2 years old, $46 \mathrm{~cm}, 940 \mathrm{~g}$ ) (Prista unpublished data) but Schiavone et al. (2012) also report a few one-year old males producing expressible milt.

Our histological analysis of meagre testes objectively confirmed the occurrence in wild populations of some small fish $(<60 \mathrm{~cm})$ with inconspicuous testes (low weight, low GSI) in spawning-capable condition that may (or may not) extrude milt upon squeezing. In histological terms these fish are considered to have reached maturity since they have spermatozoa and are therefore capable of participating in reproduction (Brown-Peterson et al. 2011). Whether or not these fish contribute significantly to the overall male reproductive output of the population and the exact extent of the implications for management of considering them as mature will be dealt with elsewhere. Here, we have shown that these fish have a mixture of adult and juvenile characters (non-tubular appearance and spermatogonia abundance throughout the year), being not only small-sized but also young. These fish are unlikely to have come from a different population and most likely represent virgin fish experiencing first maturation. We have also shown that these first maturing wild fish likely develop, spawn and regress despite being far from attaining their full reproductive potential. These results concur with those reported by Schiavone et al. (2012), which showed increasing levels of estradiol, testosterone and 11-KT plasma levels between the first and second spawning seasons, evidencing that hormonal control is not yet fully stabilized after the first reproductive event. In the wild, both meagre juveniles and meagre adults visit inshore and estuarine 
waters in spring and summer, so we hypothesize that hormonal control of testes development becomes increasingly coupled to the photoperiod variations and other environmental clues (e.g. temperature, turbidity) experienced by the fish during their seasonal presence in estuarine nursery areas and future spawning grounds (Prista et al. 2008) and that in the wild meagres may also display increasing levels of hormonal control as they migrate back-and-forth between coast and estuaries during their first years of life.

Overall, the evolutionary advantage of precocious maturity in wild fish remains unresolved. In aquaculture production, precocious maturity is considered detrimental because it diverts energy from growth to reproduction (Taranger et al. 2010) but it is possible that in wild populations the selection pressure on such precocious maturity is not very large since young meagres have fast growth rates (González-Quirós et al. 2011) and are able to quickly reach a size that protects them from most marine predators. If so, some adverse effects that precocious maturity may have on growth might be counter-balanced by the advantages collected from a more precise environmental control of spermatogenesis.

\section{ACKNOWLEDGEMENTS}

The authors would like to thank all fishers and fish merchants involved in the collection of fish samples. Thanks are also due to João Calado and several FCUL students who actively collaborated in fish sampling, to Sara Faria, who helped process the histological slides, to Cristina Nunes, who commented on an earlier draft, and to Silvia Rodríguez, who helped with the Spanish abstract. Funding for the present work was provided by FCT grant BD/12550/2003 to N. Prista and research project CORV (DGPA-MARE: 22-05-01-FDR-00036) to M. J. Costa.

\section{REFERENCES}

Abou Shabana N.M., Abd El Rahman S.H., Al Absawy M.A., Assem S.S. 2012. Reproductive biology of Argyrosomus regius (Asso, 1801) inhabiting the south eastern Mediterranean Sea, Egypt. Egyptian J. Aquat. Res. 38: 147-156. http://dx.doi.org/10.1016/j.ejar.2012.12.002

Almeida F.F.L., Kristoffersen C., Taranger G.L., Schulz R.W. 2008. Spermatogenesis in Atlantic cod (Gadus morhua): A novel model of cystic germ cell development. Biol. Reprod. 78: 27-34. http://dx.doi.org/10.1095/biolreprod.107.063669

Brown-Peterson N.J., Wyanski D.M., Saborido-Rey F., Macewicz B.J., Lowerre-Barbieri S.K. 2011. A standardized terminology for describing reproductive development in fishes. Mar. Coast. Fish. 3: 52-70. http://dx.doi.org/10.1080/19425120.2011.555724

Costa A.M. 2009. Macroscopic vs. microscopic identification of the maturity stages of female horse mackerel. ICES J. Mar. Sci. 66: 509-516. http://dx.doi.org/10.1093/icesjms/fsn216

Costa M.J., Cabral H., Costa J.L., Prista N., Lopes J.C. 2008. Corvina-legítima Argyrosomus regius: Dados biológicos para a gestão e produção aquícola de um recurso. Final Report (Project Ref: DGPA-MARE: 22-05-01-FDR-00036). Centro de Oceanografia, Faculdade de Ciências da Universidade de Lisboa, Lisboa, Portugal. [in Portuguese].

Dadzie S., Abou-Seedo F. 2004. Testicular structure and spawning cycle in the silvery croaker, Otolithes ruber (Perciformes: Sciaenidae) in the Kuwaiti waters of the Arabian Gulf. Ichthyol. Res. 51: 263-268. http://dx.doi.org/10.1007/s10228-004-0228-4

FAO, 2009. Capture Production 1950-2007. FISHSTAT Plus: Universal software for fishery statistical time series. Version 2.3. FAO Fisheries Department, Fishery Information, Data and Statistics Unit. FAO, Rome, Italy.

Farmer B. 2003. Biology of the Mulloway Argyrosomus japonicus in Western Australia. M.Sc. thesis, Murdoch Univ., 107 pp.

Farmer B. 2008. Comparisons of the biological and genetic characteristics of the Mulloway Argyrosomus japonicus (Sciaenidae) in different regions of Western Australia. Ph.D. thesis, Murdoch Univ., 217 pp.

Ferreri R., Basilone G., D'Elia M., Traina A., Saborido-Rey F., Mazzola S. 2009. Validation of macroscopic maturity stages according to microscopic histological examination for European anchovy. Mar. Ecol. 30: 181-187. http://dx.doi.org/10.1111/j.1439-0485.2009.00312.x

Gil M.M., Grau A., Basilone G., Ferreri R., Palmer M. 2013. Reproductive strategy and fecundity of meagre Argyrosomus regius Asso, 1801 (Pisces: Sciaenidae): implication for restocking programs. Sci. Mar. 77: 105-118. http://dx.doi.org/10.3989/scimar.03688.28A

González-Quirós R.R., Del Arbol J., Garcia-Pacheco M.D.M., Silva-Garcia A.J., Naranjo J.M., Morales-Nin B. 2011. Lifehistory of the meagre Argyrosomus regius in the Gulf of Cádiz (SW Iberian Peninsula). Fish. Res. 109: 140-149. http://dx.doi.org/10.1016/j.fishres.2011.01.031

Grau A., Linde M., Grau A.M. 2009. Reproductive biology of the vulnerable species Sciaena umbra Linnaeus, 1758 (Pisces: Sciaenidae). Sci. Mar. 73: 37-81. http://dx.doi.org/10.3989/scimar.2009.73n1067

Grier H.J. 2002. The germinal epithelium: Its dual role in establishing male reproductive classes and understanding the basis for indeterminate egg production in female fishes. In: Creswell R.L. (ed.), Proceedings of the Fifty-Third Annual Gulf and Caribbean Fisheries Institute. Mississipi/Alabama Sea Grant Consortium Fort Pierce, Florida, pp. 537-552.

Grier H.J., Taylor R.G., Reese R.O. 1987. The mechanism of tubule elongation during testicular recrudescence in the redfish, Sciaenops ocellatus (Perciformes). In: Kullander S.O., Femholn B. (eds), Proceedings of the 5th Congress of European Ichthyologists, Swedish Museum of Natural History, Stockholm, pp. 285-291.

Griffiths M.H. 1996. Life history of the dusky kob Argyrosomus japonicus (Sciaenidae) off the East coast of South Africa. S. Afr. J. Mar. Sci. 17: 135-154. http://dx.doi.org/10.2989/025776196784158653

Griffiths M.H. 1997. Life history and stock separation of silver kob Argyrosomus inodorus in South African waters. Fish. Bull. 95: 47-67.

Hermas J. 1995. Contribuition à l'étude des débarquements et de la biologie du maigre Argyrosomus regius (Asso, 1801) au port d'Agadir. Ph.D. thesis, Univ. Ibnou Zohr, 113 pp.

Hunter J.R., Macewicz B.J. 2003. Improving the accuracy and precision of reproductive information used in fisheries. In: Kjesbu O.S., Hunter J.R., Witthames P.R. (eds), Report of the working group on modern approaches to assess maturity and fecundity of warm- and cold-fish and squids. John Grieg Grafisk AS, Bergen, pp. 57-68.

Lowerre-Barbieri S.K., Ganias K., Saborido-Rey F, Murua H., Hunter J.R. 2011. Reproductive timing in marine fishes: Variability, temporal scales, and methods. Mar. Coast. Fish. 3: 71-91. http://dx.doi.org/10.1080/19425120.2011.556932

Morales-Nin B., Geffen A.J., Pérez-Mayol S., Palmer M., GonzálezQuirós R., Grau A. 2012. Seasonal and ontogenic migrations of meagre (Argyrosomus regius) determined by otolith geochemical signatures. Fish. Res. 127-128: 154-165. http://dx.doi.org/10.1016/j.fishres.2012.02.012

Moravec F., Prista N., Costa M.J. 2007. Meagre, Argyrosomus regius (Osteichthyes), as host of a gonad-infecting species of Philometra (Nematoda: Philometridae) off the Atlantic coast of Portugal. Dis. Aquat. Org. 78: 83-86. http://dx.doi.org/10.3354/dao01860

Murphy M.D., Taylor R. 1989. Reproduction and growth of black drum, Pogonias cromis, in Northeast Florida. NE Gulf Sci. 10: 127-137.

Murphy M.D., Taylor R. 1990. Reproduction, growth, and mortality of red drum Sciaenops ocellatus in Florida waters. Fish. Bull. 88: 531-542.

Nieland D.L., Wilson C.A. 1993. Reproductive biology and annual variation of reproductive variables of black drum in the North- 
ern Gulf of Mexico. Trans. Am. Fish. Soc. 122: 318-327. http://dx.doi.org/10.1577/1548-8659(1993)122<0318:RBAAO $>2.3 . \mathrm{CO} ; 2$

Parenti L.R., Grier H.J. 2004. Evolution and phylogeny of gonad morphology in bony fishes. Integr. Comp. Biol. 44: 333-348. http://dx.doi.org/10.1093/icb/44.5.333

Prista N., Costa J.L., Costa M.J., Jones C.M. 2007. New methodology for studying large valuable fish in data-poor situations: Commercial mark-recapture of meagre Argyrosomus regius in the southern coast of Portugal. ICES CM/O: 43, 18 pp.

Prista N., Jones C.M., Costa J.L., Costa M.J. 2008. Inferring fish movements from small-scale fisheries data: The case of Argyrosomus regius (Sciaenidae) in Portugal. ICES CM/K: 19, 19 pp.

Prista N., Costa J.L., Costa M.J., Jones C.M. 2009. Age determination in meagre, Argyrosomus regius. Rel. Cient. Téc. Inst. Invest. Pescas Mar 49: 1-54.

Prista N., Diawara N., Costa M.J., Jones C.M. 2011. Using SARIMA to assess data-poor fisheries: Case-study with a sciaenid fishery off Portugal. Fish. Bull. 109: 170-185.

Quéméner L. 2002. Le maigre commun (Argyrosomus regius) - Biologie, pêche, marché et potentiel aquacole. Éditions Ifremer, Plouzané, $31 \mathrm{pp}$.

Quéméner L., Suquet M., Mero D., Gaignon J.-L. 2002. Selection method of new candidates for finfish aquaculture: The case of the French Atlantic, the Channel and the North Sea Coasts. Aquat. Living Resour. 15: 293-302. http://dx.doi.org/10.1016/S0990-7440(02)01187-7

Quéro J.-C., Vayne J.-J. 1987. Le maigre, Argyrosomus regius (Asso, 1801) (Pisces, Perciformes, Sciaenidae) du Golfe de
Gascogne et des eaux plus septentrionales. Rev. Trav. Inst. Pêches Marit. 49: 35-66.

Rideout R., Tomkiewicz J. 2011. Skipped spawning in fishes: More common than you might think. Mar. Coast. Fish. 3: 176-189. http://dx.doi.org/10.1080/19425120.2011.556943

Schiavone R., Zilli L., Storelli C., Vilella S. 2012. Changes in hormonal profile, gonads and sperm quality of Argyrosomus regius (Pisces, Sciaenidae) during the first sexual differentiation and maturation. Theriogenology 77: 888-898. http://dx.doi.org/10.1016/j.theriogenology.2011.09.014

Schulz R.W, França L.R., Lareyre J.-J., LeGac F., Chiarini-Garcia H., Nobrega R.H., Miura T. 2011. Spermatogenesis in fish. Gen. Comp. Endocrinol. 165: 390-411. http://dx.doi.org/10.1016/j.ygcen.2009.02.013

Taranger G.L., Carrillo M., Schulz R.W., Pascal F., Zanuy S., Felip A., Weltzien F.-A., Dufour S., Karlsen Ø., Norberg B., Andersson E., Hansen T. 2010. Control of puberty in farmed fish. Gen. Comp. Endocrinol. 165: 483-515 http://dx.doi.org/10.1016/j.ygcen.2009.05.004

Tixerant G. 1974. Contribuition à l'étude de la biologie du maigre ou courbine sur la côte Mauritanienne. Ph.D. thesis, Univ. d'Aix-Marseille, 123 pp.

West G. 1990. Methods of assessing ovarian development in fishes: A review. Aust. J. Mar. Freshw. Res. 41: 199-222. http://dx.doi.org/10.1071/MF9900199

Wilson C.A., Nieland D.L. 1994. Reproductive biology of red drum, Sciaenops ocellatus, from the neritic waters of the northern Gulf of Mexico. Fish. Bull. 82: 841-850. 